\title{
Endophytic Microorganism From the Endangered Plant Nervilia Fordii (Hance) Schltr. In the Southwest Karst Area of China: Isolation, Genetic Diversity and Potential Functional Discovery
}

\author{
Xiao-Ming Tan \\ Guangxi University of Chinese Medicine, Guangxi Key Laboratory Cultivation Base of TCM Prevention and Treatment of Obesity \\ Xin-Feng Yang \\ Guangxi University of Chinese Medicine, Guangxi Key Laboratory Cultivation Base of TCM Prevention and Treatment of Obesity \\ Ya-Qin Zhou ( $\nabla$ zhouyaqin2009@126.com) \\ Guangxi Botanical Garden of Medicinal Plant \\ Peng Fu \\ Guangxi University of Chinese Medicine, Guangxi Key Laboratory Cultivation Base of TCM Prevention and Treatment of Obesity \\ Shi-Yi Hu \\ Guangxi University of Chinese Medicine, Guangxi Key Laboratory Cultivation Base of TCM Prevention and Treatment of Obesity \\ Zhong-Heng Shi \\ Guangxi University of Chinese Medicine, Guangxi Key Laboratory Cultivation Base of TCM Prevention and Treatment of Obesity
}

\section{Research Article}

Keywords: Nervilia fordii, vulnerable perennial herb, Bletilla striata seeds, various endophytic fungi, orchids

Posted Date: April 27th, 2021

DOI: https://doi.org/10.21203/rs.3.rs-413613/v1

License: () (1) This work is licensed under a Creative Commons Attribution 4.0 International License. Read Full License 


\section{Abstract}

The plant Nervilia fordii (Hance) Schltr. is known for its antimicrobial and antitumor properties. It is a rare and vulnerable perennial herb of the Orchidaceae family. In this study, 984 isolates were isolated from various tissues of $N$. fordii. and were identified through the sequence analyses of the internal transcribed spacer region of the rRNA gene. Except for 12 unidentified fungi, all others were affiliated to at least 39 genera of 14 orders of Ascomycota (72.66\%) and Basidiomycota (19.00\%). Antimicrobial activity was determined by using the agar diffusion method. Subsequent assays revealed 20 strains of fungal endophytes exhibited antibacterial activity against at least one pathogenic bacterium or fungus. Moreover, the capability of promoting seed germination was evaluated on the basis of the interaction of Bletilla striata seeds with the isolates. Results revealed that the three isolates could promote $B$. striata seed germination. After 21 days, the germination rate under treatment with the best strain was $97.89 \%$, which was higher than that under the control treatment $(12.68 \%)$. Taken together, the present data suggested that various endophytic fungi of $N$. fordii could be exploited as sources of novel natural antimicrobial agents or used for the artificial breeding of rare orchids.

\section{Introduction}

Endophytic fungi have been detected in all plant species investigated thus far ${ }^{1}$. They inhabit living plant tissues for at least parts of their life cycles without causing any apparent disease or injury to their host ${ }^{2}$ and are ubiquitous in vascular plant species ${ }^{3}$. All orchids require endophytic fungi. They play a key role in supporting and enhancing plant health and growth ${ }^{4,5}$, such as produce different plant hormones to enhancing plant growth ${ }^{6}$, protecting the host plant against phytopathogenic microorganisms or pests ${ }^{7,8}$ and so on. In addition, they can influence plant ecology; fitness; the evolution of plant community structures; and the diversity of interacting organisms, including nematodes and insects ${ }^{9,10}$. Endophytes represent a relatively underexplored and attractive source of natural products that are suitable as novel sources of bioactive metabolites, including metabolites with anticancer, antimicrobial, antimalarial, and other activities, and have thus elicited considerable attention from many researchers ${ }^{11,12}$. Currently, although many endophytic fungi from various terrestrial plants are gradually being described and explored, they account for less than $10 \%$ of the approximately one million known terrestrial endophytes have been investigated ${ }^{13}$.

Nervilia fordii (Hance) Schltr. (Fig. 1 a) is a rare and vulnerable perennial herb of the Orchidaceae family; the whole plant (including rhizome, Fig. 1 b) or the aerial part is used as a traditional Chinese medicine called Qing Tian Kui ${ }^{14,15}$. This plant species is endemic to the southwest karst area of China (Fig. $1 \mathrm{c}$ ) and is mainly distributed at altitudes ranging from $220-1,000 \mathrm{~m}$ above sea level in sheltered valley or hillside areas ${ }^{16,17} . N$. aragoana, $N$. cumberlegii, $N$. fordii, $N$. lanyuensis, N. mackinnonii, N. plicata (Andr.) Schltr. var. plicata, N. taiwaniana, and N. plicata (Andr.) Schltr. var. purpurea (Hayata) S. S. Ying have been identified as endemic to China in previous studies ${ }^{18}$. N. fordii is a traditional Chinese medicine that has long been used in Chinese folk medicine for the treatment of various respiratory diseases, such as bronchitis, stomatitis, acute pneumonia, and acute pharyngitis ${ }^{19,20}$. N. fordii has received considerable attention in modern pharmacology research because of its biological behaviors, which include antimicrobial ${ }^{21}$, antitumor $^{22}$, antiviral ${ }^{23}, a^{2} a^{2}{ }^{2} i-$ inflammatory ${ }^{24}$ behaviors.

Therefore, the present work aimed to investigate the species diversity of the culturable endophytic fungi in $N$. fordii collected from Guangxi Provinces, China, via rDNA internal transcribed spacer (ITS) sequences analysis. The endophytic fungi were screened for antimicrobial activities, and their benefit to seed germination was determined. The results of this report are helpful for exploring the potential sources of novel natural antimicrobial and the actual propagation and conservation of orchids.

\section{Materials And Methods}

Ethics Committee approval was obtained from the Institutional Ethics Committee of Guangxi University of Chinese Medicine to the commencement of the study. We confirm that all methods were performed in accordance with the relevant guidelines and regulations.

Collection of plant material. In 2020, he samples of $N$. fordii wild plants were collected from Sanhaung Townlet, Guangxi Province, China (109 $66^{\prime} \mathrm{E} ; 24^{\circ} 94^{\prime} \mathrm{N}$ ). Healthy $N$. fordii plants were selected. Whole plants were dug out and placed in pots with rhizosphere soil and environmental soil, labeled, and transported to the laboratory within $12 \mathrm{~h}$. The plant specimens were identified by Professor Tan and were preserved in the herbarium of the the Guangxi Botanical Garden of Medicinal Plants (voucher ID: SHNF20200618).

Fungal isolation and cultivation. Endophytic fungi were isolated from the corms, rhizomes, and leaves of the plant specimens. Procedures for the surface sterilization of plant tissues and the isolation and cultivation of fungi have been previously described by Tan et al. ${ }^{3,10}$. Briefly, roots, rhizomes, and leaves were separated from the plants; washed thoroughly in running tap water to remove dirt; and surface-sterilized sequentially in $70 \%$ ethanol ( $/ \mathrm{v}$ ) for $30 \mathrm{~s}$ and sodium hypochlorite solution $(2.5 \%, \mathrm{v} / \mathrm{v})$ for $5 \mathrm{~min}$. All tissues were then rinsed three times with sterile distilled water and were surface-dried with sterile filter paper.

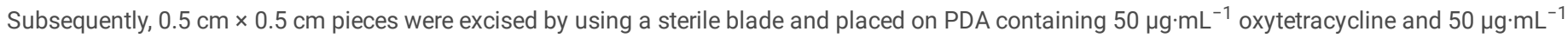
streptomycin. Seven segments were plated per Petri dish $\left(90 \mathrm{~mm}\right.$ diameter). The Petri dishes were then wrapped in parafilm and incubated at $25^{\circ} \mathrm{C}$ in the dark. They were observed for the growth of fungi from the segments every 2 days for more than 1 week. The colonies were routinely isolated, purified, and maintained in PDA for identification and antimicrobial assays. Pure endophytic fungi were finally photographed and preserved in the Scientific Laboratory Center, Guangxi University of Chinese Medicine.

DNA extraction, PCR amplification, sequencing, and molecular identification. For the production of fungal mycelia, all strains were grown on PDA plates at 25 ${ }^{\circ} \mathrm{C}$ for 1-2 weeks (the diameter of fungal colony was approximately $4 \mathrm{~cm}$, which could meet the requirement of DNA extraction). Mycelia were scraped by using sterile pipette tips and were then freeze-dried, DNA from endophytic fungi was then extracted using by E.Z.N.A.TM Fungal DNA Mini Kits (Omega Bio-tek, Norcross, USA) were utilized in accordance with the manufacturers' instructions for use as templates in polymerase chain reactions (PCR). The primers ITS1 
(5'-TCCGTAGGTGAACCTGCGG-3') and ITS4 (5'-TCCTCCGCTTATTGATATGC-3') were constructed for molecular phylogenetic studies and were used to amplify ribosomal internal transcribed spacers (ITS) ${ }^{56}$ The PCR mixture $(50 \mu \mathrm{L}$ ) contained $25 \mu \mathrm{L}$ of $2 \times$ SanTaq PCR Mix (Sangon Biotech, Shanghai), $2 \mu \mathrm{L}$ of each primer $(5 \mu \mathrm{M})$, and $2-10 \mu \mathrm{L}$ of genomic DNA $\left(20-50 \mathrm{ng} \cdot \mu \mathrm{L}^{-1}\right)$ and brought to a volume of $50 \mu \mathrm{L}$ with ddH $\mathrm{H}_{2} \mathrm{O}$. PCR was performed on a thermal cycler (BioRAD) as follows: incubation at $94{ }^{\circ} \mathrm{C}$ for $3 \mathrm{~min}$; followed by 35 cycles of $94{ }^{\circ} \mathrm{C}$ for $30 \mathrm{~s}, 55^{\circ} \mathrm{C}$ for $25 \mathrm{~s}, 72{ }^{\circ} \mathrm{C}$ for $30 \mathrm{~s}$; and then a final extension step at $72{ }^{\circ} \mathrm{C}$ for 7 min. Subsequently, PCR products were purified and sequenced at the Shanghai Sangon Biological Engineering Technology \& Services Co. Ltd. The sequences were then BLASTed the sequences of known isolates in the NCBI database (http://www.ncbi.nlm.nih.gov) ${ }^{57}$. Only those matching previously published sequences with high similarity were used. All identified isolates were categorized at the genus or family levels in accordance with the ownership criterion as follows: species of the same genera had sequence similarity (SS) $\geq 95 \%$ and those of the same families had SS $\leq 95 \% 58,59$.

Antimicrobial activity. Three pathogens, including the fungi $C$. tropicalis and bacteria $E$. coli and $S$. aureus, were used to test the antimicrobial activities of all strains. Inhibitory effects were assayed by using the fungus cake method ${ }^{60}$. Streptomycin $\left(20 \mu \mathrm{L}, 5 \mathrm{mg} \cdot \mathrm{mL}^{-1}\right)$ and tetracycline $\left(20 \mu \mathrm{L}, 5 \mathrm{mg} \cdot \mathrm{mL}^{-1}\right) \mathrm{were} \mathrm{used}$ as positive antimicrobial controls, and PDA agar plugs were used as the negative control. Antimicrobial activities were determined in accordance with the diameters of ZI. Experiments were repeated three times.

Effects of fungal strains on seed germination. All strains were grown on PDA at $25^{\circ} \mathrm{C}$ in the dark. After 10 days, five PDA agar plugs (diameter of 2 mm) with active mycelial growth from the colony margin were inoculated into a Petri dish (diameter $9 \mathrm{~mm}$ ) containing $15 \mathrm{~mL}$ of sterile oatmeal agar (2.5 g. $\mathrm{L}^{-1}$ oatmeal, $12 \mathrm{~g} \cdot \mathrm{L}^{-1}$ agar, and $\mathrm{pH}$ of 5.2 prior to autoclaving) with five pieces of nylon cloth $(1 \times 1 \mathrm{~cm})$, and grown at $25^{\circ} \mathrm{C}$ in dark ${ }^{61,62}$. The seeds of the terrestrial orchid plant $B$. striata were selected as the experimental subject for seasonal reasons. The seeds were surface sterilized with sodium hypochlorite solution for 10 min to remove fungal contamination. After 1 week, approximately 150 axenic seeds of $B$. striata (Fig. 3 a) were sown on the surface of each piece of cloth. Each treatment was replicated on five plates. The treatment without fungi was used as the control. All treatments were placed in a tissue culture chamber under 12 h of light exposure at $25^{\circ} \mathrm{C}$ for 70 days. A stereomicroscope (LEICA TL3000 Ergo) was used to assess and record seed germination and protocorm development. Stewart et al. ${ }^{63}$ had divided the seed germination and protocorm development of orchids into six stages $(0-5)$. Three seedling growth stages were added in this study as shown in Table 3 showing as a referencefor assessing the percentage of seed germination and protocorm development of $B$. striata.

Statistical analyses. The IR\% of the strains were calculated as follows: IR\% $=(\mathrm{Ni} / \mathrm{Nt}) \times 100$, where Ni represents the number of segments from which the fungal species was isolated, and $\mathrm{Nt}$ is the total number of segments incubated ${ }^{64}$. The percentages of seed germination for per stage were calculated by using the following formula ${ }^{61}$ :

Percentage of seeds germination

$=\frac{\text { Number of seeds in per germination stage }}{\text { Total number of viable seeds in the sample }} \times 100$

The diversity of fungal species from $N$. fordii was evaluated by using the $H^{\prime}$ and $J$ with the following formulas:

$H^{\prime}=-\Sigma(P i x \ln P i)(P i=n i / N)$

$J=H^{\prime} / \ln (S)$

where $\mathrm{S}$ represents the total species numbers of endophytic fungi in the community, ni represents the numbers of individuals, and $\mathrm{N}$ represents the total number of individuals ${ }^{65,66}$. All statistical analyses were performed using by SPSS 19.0 (SPSS Inc., Chicago, IL, USA).

\section{Results}

Isolation, sequencing data, and diversity of culturable endophytic fungi. In this study, 984 fungal colonies (isolation rate\% [IR] = $78.03 \%$ ) were isolated from 1261 tissue segments of $N$. fordii plants. The 984 isolates were assigned to 124 strains in accordance with their culture characteristics on potato dextrose agar (PDA) (Fig. 1 d) and ITS rDNA sequence analyses. They included 51 (41.13\%), 48 (38.04\%), and 76 (61.29\%) strains from rhizome, corm, and leaf tissue segments, respectively (Table 1). Except for 12 unidentified fungi without high similarity in the GenBank database, all 112 isolates were categorized at the species, genus, or family level ( Table 1).

At least 39 fungal genera were identified in accordance with the diversity and sequence data of the 112 isolates recovered from $N$. fordii plants. Among the 39 genera, 36 were affiliated with phylum Ascomycota and included 715 isolates (72.66\%). Three (19.00\%) strains were classified as Basidiomycota, comprising Epulorhiza, which is affiliated with Tulasnellaceae; and Phanerochaete cf., which is affiliated with Phanerochaetaceae.

Further analyses revealed that most isolates belonged to four classes, including Eurotiomycetes, Dothideomycetes, Sordariomycetes, and Leotiomycetes. Further taxonomic analysis showed that most of the isolates $(n=495)$ from $N$. fordii belonged to class Sordariomycetes. This class was represented by six orders, namely, Sordariales, Glomerellales, Hypocreales, Xylariales, Diaporthales, and Magnaporthales; and 17 genera: Amesia, Chaetomium, Colletotrichum, Cylindrocarpon, Fusarium, Ilyonectria, Nectria, Volutella, Corallomycetella, Lecanicillium, Arthrinium, Obolarina, Xylaria, Daldinia, Diaporthe, Phomopsis, Leptostroma, and an unknown Magnaporthaceae genus. 181 isolates were assigned to class Dothideomycetes, comprising the five orders of Pleosporales, Cladosporiales, Muyocopronales, Venturiales and Botryosphaeriales and 15 genera (Acrocalymma, Letendraea, Periconia, Ascochyta, Epicoccum, Phoma, Alternaria, Bipolaris, Exserohilum, Sclerostagonospora, Torula, Dictyosporium, Cladosporium, Mycoleptodiscus and Phyllosticta,). 34 isolates were assigned to 
class Eurotiomycetes, and orders Eurotiales and Chaetothyriales, representing the genera Aspergillus, Penicillium, Talaromyces, and Rhinocladiella. Finally, five isolates were assigned to class Leotiomycetes and classified as genus Leptostroma of the order Rhytismataceae.

The exclusion of 12 unidentified fungi (2.85\%) failed to show that the endophytes were widely distributed. The Shannon-Weiner diversity index $\left(H^{\prime}\right)$ was estimated on the basis of taxonomic units or morphological characters. ITS sequences showed that the corm segment presented the highest fungal species diversity (2.686), followed by the rhizome (1.923) and leaf (1.976) segments. The corme segment showed a higher Pielou Evenness index $(J)(0.835)$ than the rhizome (0.565) and leaf (0.600) segments (Table 1).

In the present data, endophytic fungi were highly abundant and diverse in the rhizomes of $N$. fordii and that the most ubiquitous phylum of fungi was Ascomycota, which is reportedly among the most prevalent group of eukaryotes globally $25,26,27$. Eurotiomycetes was the most prevalent class of endophytic fungi, followed by Dothideomycetes. Moreover, $47.87 \%$ of endophytic fungi were present in the corm and rhizome of $N$. fordii, and $52.13 \%$ of the fungal isolates were found in the leaves of $\mathrm{N}$. fordii. The genera of Epulorhiza, Alternaria, Phoma, Sclerostagonospora, Torula, llyonectria, Purpureocillium, Amesia, Corallomycetella, and Daldinia colonized rhizomes, whereas Periconia, Dictyosporium, Volutella, and Lecanicillium were exclusively detected in corms. In addition, Arthrinium (26.83\%) was the most common fungal genus in $N$. fordii that was abundant in the leaves but was less abundant in corms and rhizomes. The dominant genera of $N$. fordii also included Colletotrichum $(10.26 \%$, mainly colonizing the leaves) and Tulasnellaceae ( $16.97 \%$, mainly colonizing the rhizomes).

Antimicrobial activity of culturable endophytic fungi from $\mathbf{N}$. fordii. A total of 20 fungal isolates that effectively inhibited pathogen growth were screened out by using the agar diffusion method. The antimicrobial fungi belonged to the genera Penicillium, Aspergillus, Epicoccum, Alternaria, Fusarium, Bipolaris, Cylindrocarpon, Phoma, Lecanicillium, Amesia, Sclerostagonospora, and Arthrinium and included ascomycete and fungal endophyte species (Table 2). Among these fungi, 13 strains (9.33\%) showed antibacterial activity against Escherichia coli, 14 strains (12.30\%) demonstrated activity against Staphylococcus aureus, and 2 strains (2.33\%) presented activity against Candida tropicalis. Notably, Penicillium sp. (1151, Fig. 2 a-b) showed the highest activity against all pathogens. The diameter of the inhibition zone (ZI) against E. coli was $34.698 \mathrm{~mm}$ (Fig. $2 \mathrm{c}$ ), which was 1.42 times that against streptomycin and 1.31 times that against tetracycline. The diameter of the Zl against S.aureus was $28.478 \mathrm{~mm}$ (Fig. $2 \mathrm{~d}$ ) and was 1.22 and 1.15 times that against the positive control, respectively. However, no activity against $C$. tropicalis was observed. In addition, Epicoccum sp. (1243) and Phoma sp. (1244, Fig. 1 d) had better antimicrobial effect against $E$. coli $(1243 \mathrm{ZI}=18.515 \mathrm{~mm} ; 1244 \mathrm{ZI}=20.690 \mathrm{~mm})$ and $S$. aureus $(1243 \mathrm{ZI}=19.540 \mathrm{~mm} ; 1244 \mathrm{ZI}=21.298 \mathrm{~mm})$ than the other strains . Comparison with the positive control group revealed that the antibacterial activities of the strains against the two pathogens exceeded $70 \%$.

Interestingly, the fungi have different antimicrobial activity which isolated from different parts of $N$. fordii. And those that were mainly distributed in the rhizome. However, further studies are required to characterize the dynamic changes in endophytic communities ${ }^{28}$ and uncultured fungi ${ }^{29}$ and to confirm fungal tissue specificity ${ }^{30}$ in $N$. fordii. The results suggested that endophytic fungi from $N$. fordii. are potential sources of natural antimicrobial products.

Seed germination trials. This study aimed to obtain isolates with high seed germination activities from $N$. fordii plants. The seeds of the orchid plant Bletilla striata were selected as the experimental subject for seasonal reasons.

The results showed that Arthrinium sp. (1130 and 1232) and Tulasnellaceae sp. (1217, Fig. $1 \mathrm{~d}$ ) had higher seed germination activity than the CK group. After 28 days, tthe germination rate of the seeds treated with the two endophytic Arthrinium species increased by $0.37 \%$ compared with that of the CK group. After 3 weeks $₫$ treatment with the two Arthrinium isolates increased the germination of $B$. striata seeds up to the emergence of first leaf by $27.63 \%$ and $2.72 \%$, respectively. Arthrinium sp. (1130) promoted seed germination up to the elongation of the secand leaf stage $(0.63 \%)$ after 4 weeks, and the dominant seed germination stage was the emergence of the second leaf stage (33.54\%). The germination rate during this stage increased by $33.14 \%$ compared with that under treatment with the CK. After 4 weeks, Arthrinium sp. (1232) promoted seed germination up to the emergence of the second leaf stage (0.39\%) and stage 4 was the dominant stage (33.54\%). The germination rate in the treatment group increased by $18.90 \%$ compared with that in the CK group. After 7 weeks, the two strains of Arthrinium promoted seed germination up to the appearance of root stage by $73.17 \%$ and $21.05 \%$, respectivelybut. Without symbiotic fungi, seed development of B.striata was arrested at stage 7 (Fig. 4. a). The above data indicated that the two Arthrinium isolates had a certain capability to promote seed germination.

Tulasnellaceae sp. (1217) had the best germination-promoting activity (Fig. 3 a-f). After 3 weeks, the rate of seed germination under treatment with Tulasnellaceae sp. was $97.89 \%$, which was significantly higher than that under treatment with CK (85.21\%). After 7 weeks of sowing, roots appeared in $52.41 \%$ of $B$. striata seeds, and the uninoculated control showed a germination rate of zero (Fig. 4 b). B. striata seedlings in the experimental group had more roots and larger leaves than the seedlings in other groups. The fresh weight and plant height of the $B$. striata seedlings in the experimental group were 1.22 and 3.34 times higher than those of the seedlings in the control group. Most of the seedlings demonstrated root germination. The total germinated root number and root length of the treated seedlings were 13.55 and 6.07 times those of the control, respectively.

\section{Discussion}

Endophytes affect the the quality and quantity of the crude drugs through specific fungus-host interactions ${ }^{31,32}$. They are widely considered as valuable natural resources with diverse applications in a variety of areas, such as agriculture and biotechnology ${ }^{33}$. Most endophytic fungi from wild orchids have been studied. However, studies on endophytic fungi from Nervilia plants, particularly studies fungi related to biological activity, have rarely been conducted.

In this study, 112 strains of endophytic fungi belonging to tow phyla, five classes, 16 orders, 28 family and 39 genera were obtained from $N$. fordii. Consistent with the findings of Song et al. ${ }^{34}$, Arthrinium, Colletotrichum, and Tulasnellaceae were found to be the dominant endophytic fungi of $N$. fordii and accounted for more than $10 \%$ of the total endophytes. 
The quantities of endophytic fungi varied across different plant tissues from $N$. fordii. The corm of $N$. fordii. harbored the highest number of endophytic fungi. The variation in the quantities of endophytic fungi across different plant tissues might be ascribed to environmental differences between the above- and below-ground parts of plants; for example, the roots are highly susceptible to infestation by soil microorganisms due to their long-term presence and close interaction in the soil ${ }^{35}$. Isolates Ascomycota sp. (1192 and 1299, Fig. $1 \mathrm{~d}$ ) and Venturiaceae sp. (1300) had darkly pigmented and septate hyphae of thick walls. These strains are often referred to as dark septate fungi (DSE) ${ }^{36}$ and are isolated from corms. Mandyam \& Jumpponen suggested that DSE-plant symbioses are multifunctional and play unique roles in terrestrial ecosystems ${ }^{37}$. They participate in nutrient acquisition and in the resultant positive host growth responses ${ }^{38,39}$. The isolation of 20 strains exhibiting strong antimicrobial activity indicated that these plants and their endophytes could be potential sources of novel natural antimicrobials. These strains belonged to 12 genera and one to fungal species, thus illustrating the diversity of the distribution of endophytic fungal genera with antibacterial activity. Phoma, Fusarium and Penicillium, which have been isolated from medicinal orchids, exhibit antibacterial activity. Several endophytic fungi with high antioxidant capacities, such as Alternaria, Fusarium, Xylaria, and Penicillium, have been isolated from Dendrobium ${ }^{40,41}$. Similarly, Lecanicillium, Phoma, and llyonectria isolated from Dysosma versipellis possess antibacterial activity 3,42 . Penicillium sp. (1151) with the best antibacterial activity was screened. The secondary metabolites produced by Penicillium sp. have consistently shown good biological activity in antibacterial activities. The well-known antibacterial drugs penicillin and griseofulvin were isolated from Penicillium chrysogenum ${ }^{43}$ and Penicillium griseofulvum ${ }^{44}$, which are commonly found in nature. Furthermore, endophytic fungi of Penicillium fungal species that have been isolated from some herbal plants, such as Pogostemon cablin ${ }^{45}$, Withania somnifera ${ }^{46}$, and Panax ginseng Meyer ${ }^{47}$ have also been shown to possess a variety of antibacterial activities.

Orchidaceae are typical mycorrhizal plants. Their seeds are tiny, without endosperm and must depend on suitable mycorrhizal fungi to germinate in natural conditions ${ }^{48}$. Symbiotic seed germination has been practically used in orchid recovery projects worldwide and is considered as an effective way for orchid conservation ${ }^{49,50}$. Seed germination trials confirmed the capability of Arthrinium sp. (1130 and 1232) and Tulasnellaceae (1217) to enhance the germination of $B$. striata, among which 1217 had the best seed germination-promoting activity. Previous studies have demonstrated that the majority of orchid mycorrhizal symbionts fall under the broad category of Rhizoctonia-like fungi, whose members include Tulasnellaceae, and constitute an important class of symbiotic germinating fungi ${ }^{51,52}$. Among the reported orchids, fungi of the Tulasnellaceae can promote seed germination in several species of orchids (approximately 40 species), such as Dendrobium, Epidendrum secundum, Chiloglottis, Dichromanthus and so on $53,54,55$.

Endophytic fungi were highly abundant in $N$. fordii plants and exhibited a wide range of biological activities. However, their ecological function, relevant metabolic pathways, and secondary metabolites need extensive investigation. These species are potential viable sources for the exploration of novel natural products and the actual propagation of other orchid species.

\section{Declarations}

\section{Acknowledgements}

This work was supported by the National Natural Science Foundation of China (NSFC, Project No. 31860128), the Guangxi Science Foundation (Project No. 2019GXNSFDA245017) and the Innovation and entrepreneurship training program of Guangxi University of traditional Chinese Medicine (Project No. 202010600176). And we are grateful to Dr. Dawei Zhang (Jiangsu University of Technology) for guiding the revision of this manuscript.

\section{Author Contributions}

X.-M. T., P. F. and Y.-Q. Z. conceived and designed the experiments. X.-F. Y., X.-M. T., S.-Y. H. and Z.-H. S. performed the experiments. Y.-Q. Z. and X.-F. Y. analyzed the data. X.-M. T. and X.-F. Y. wrote the manuscript. All authors reviewed the manuscript.

\section{References}

1. Hardoim, P. R. et al. The Hidden World within Plants: Ecological and Evolutionary Considerations for Defining Functioning of Microbial Endophytes. Microbiology \& Molecular Biology Reviews Mmbr. 79, 293-320 https://doi.org/10.1128/mmbr.00050-14 (2015).

2. Wemheuer, F., Wemheuer, B., Daniel, R. \& Vidal, S. Deciphering bacterial and fungal endophyte communities in leaves of two maple trees with green islands. Sci Rep. 9, 14183 https://doi.org/10.1038/s41598-019-50540-2 (2019).

3. Tan, X. M. et al. Diversity and bioactive potential of culturable fungal endophytes of Dysosma versipellis; a rare medicinal plant endemic to China. Sci Rep. 8, 5929 https://doi.org/10.1038/s41598-018-24313-2 (2018).

4. Hadacek, F. \& Kraus, G. F. Plant root carbohydrates affect growth behaviour of endophytic microfungi. FEMS Microbiol. Ecol. 41, 161-170 https://doi.org/10.1016/S0168-6496(02)00292-1 (2002).

5. Sessitsch, C. Plant growth-promoting bacteria in the rhizo- and endosphere of plants: their role, colonization, mechanisms involved and prospects for utilization. Soil Biology and Biochemistry. 42, 669-678 https://doi.org/10.1016/j.soilbio.2009.11.024 (2010).

6. Waqas, M., Khan, A. L., Kamran, M., Hamayun, M. \& Lee, I. J. Endophytic fungi produce gibberellins and indoleacetic acid and promotes host-plant growth during stress. Molecules. 17, 10754-10773 (2012).

7. Gunatilaka, A. A. L. Natural products from plant-associated microorganisms: distribution, structural diversity, bioactivity, and implications of their occurrence. J NAT PROD. 69, 509-526 (2006).

8. Estrada, C., Wcislo, W. T. \& Bael, S. Symbiotic fungi alter plant chemistry that discourages leaf-cutting ants. New Phytol. 198, 241-251 (2013).

9. Rodriguez, R. J., Jr, J., Arnold, A. E. \& Redman, R. S. Fungal endophytes: diversity and functional roles. New Phytol. 182, 314-330

https://doi.org/10.1111/j.1469-8137.2009.02773.x (2009).

Page 5/12 
10. Tan, X. M. et al. Isolation and Identification of Endophytic Fungi in Roots of Nine Holcoglossum Plants (Orchidaceae) Collected from Yunnan, Guangxi, and Hainan Provinces of China. Curr Microbiol. 64, 140-147 https://doi.org/10.1007/s00284-011-0045-8 (2012).

11. Aly, A. H., De Bbab, A., Kjer, J. \& Proksch, P. Fungal endophytes from higher plants: a prolific source of phytochemicals and other bioactive natural products. Fungal Divers. 41, 1-16 https://doi.org/10.1007/s13225-010-0034-4 (2010).

12. Jalgaonwala, R. E., Mohite, B. V. \& Mahajan, R. T. A review: Natural products from plant associated endophytic fungi. World J Microbiol Biotechnol. World J Microbiol Biotechnol. 1, 21-32 (2010).

13. Ganley, R. J., Brunsfeld, S. J. \& Newcombe, G. A community of unknown, endophytic fungi in western white pine. PNAS. 101, 10107-10112 https://doi.org/10.1073/pnas.0401513101 (2004).

14. Guangdong Food and Drug Administration. Standard of traditional Chinese medicine in Guangzhou Province Vol. 1P 122(Guangdong Science and Technology Press, Guangzhou, 2004).

15. Xu, H. H. \& Liu, J. M. 'Dictionary of Zhong Cao Yao T u PuP 264(Guangdong Science and Technology Press, Guangzhou, 2007).

16. Delectis florae reipublicae popularis sinicae agendae academiae sinicae edita. Flora Reipublicae Popularis Sinicae (Vol. 18). (Beijing: Science Press, $P$ 21-22, 1999).

17. Liang, Y. S., Gong, L., Huang, Z. H. \& Ouyang, P. Y. Analysis of Global Ecological Suitability of Southern Chinese Materia Medica Herba Nervilia fordii. Subtropical Plant Science. 46, 339-342 (2017).

18. Wu, Z. Y., Raven, P. H. \& Hong, D. Y. Flora of China (Vol. 25) 5760-62(Missouri Botanical Garden Press and Science Press, Beijing, 2009).

19. Mei, Q. X. Advance in the Research of Chemical Constituent Pharmacologic Action and Clinical Application of Herba Nerviliae Plicatae. Chin Arch Tradit Chin Med. 26, 2239-2241 (2008).

20. Huang, M. Q. et al. Protection of Total Flavonoid Fraction from Nervilia fordii on Lipopolysaccharide-induced Acute Lung Injury in Rats. Chinese Herbal Medicines. 4, 287-293 https://doi.org/10.3969/j.issn.1674-6348.2012.04.005 (2012).

21. Xiong, M. et al. Antibacterial activity of folium Nerviliae in vitro. Progress in Modern Biomedicine. 14, 2753-2756 (2014).

22. Zhen, H. S. et al. Study on the anticancer effect in vitro of flavonoids compounds obtained from Nervilia fordii(hance) schltr. Chinese Journal of Experimental Traditional Medical Formulae. 14, 36-38 (2008).

23. Tian, L. W., Pei, Y., Zhang, Y. J., Wang, Y. F. \& Yang, C. R. 7-0-methylkaempferol and -quercetin glycosides from the whole plant of Nervilia fordii. Journal of Natural Products. 72, 1057-1060 https://doi.org/10.1021/np800760p (2009).

24. Zhou, G. X., Lu, C. L., Wang, H. S. \& Yao, X. S. An acetyl flavonol from Nervilia fordii (Hance) Schltr. J Asian Nat Prod Res. 11, 498-502 https://doi.org/10.1080/10286020902893074 (2009).

25. Sun, Y. et al. Endophytic fungi associated with two Sauaeda species growing in alkaline soil in China. Mycosphere. 2, 239-248 (2011).

26. Zare, R. et al. Gibellulopsis, a suitable genus for Verticillium nigrescens, and Musicillium, a new genus for V. theobromae. Nova Hedwigia. 85 (3-4), 463489 (2007).

27. Pereiro, M. et al. Cutaneous infection caused by Alternaria in patients receiving tacrolimus. Med. Mycol. 42 (3), $277-282$ (2004).

28. Kõiv, V. et al. Microbial population dynamics in response to Pectobacterium atrosepticum infection in potato tubers. Sci Rep. 5, 11606 https://doi.org/10.1038/srep11606 (2015).

29. Tejesvi, M. V. et al. Bioactivity and genetic diversity of endophytic fungi in Rhododendron tomentosum Harmaja. Fungal Divers. 47, 97-107 (2011).

30. Singh, D. K. et al. Diversity of endophytic mycobiota of tropical tree Tectona grandis Linn.f.: Spatiotemporal and tissue type effects. Sci Rep. 7, 3745 https://doi.org/10.1038/s41598-017-03933-0 (2017).

31. Fagan, F. W. F. Fungal endophytes: common host plant symbionts but uncommon mutualists. Integrative and Comparative Biology42, (2002).

32. Min, J. et al. A Friendly Relationship between Endophytic Fungi and Medicinal Plants: A Systematic Review. FRONT MICROBIOL. 7, 1-14 https://doi.org/10.3389/fmicb.2016.00906 (2016).

33. Aly, A. H., Debbab, A. \& Proksch, P. Fifty years of drug discovery from fungi. Fungal Divers. 50, https://doi.org/10.1007/s13225-011-0116-y (2011).

34. Song, L. S., Jiang, N., Lan, Z. Z., Guo, X. Y. \& Zhang, Z. J. Identification and antibacterial activity of the endophytic fungus of the endangered medicinal plant, Nervilia fordii. Jiangsu Agricultural Sciences. 47, 175-178 https://doi.org/10.15889/j.issn.1002-1302.2019.21.041 (2019).

35. Schulz, B. \& Boyle, C. The endophytic continuum. Mycol. Res. 109, 661-686 https://doi.org/10.1017/S095375620500273X (2005).

36. Jumpponen, A. \& Trappe, J. M. Dark septate endophytes: a review of facultative biotrophic root-colonizing fungi. New Phytol. 140, 295-310 (1998).

37. Mandyam, K. \& Jumpponen, A. Seeking the elusive function of the root-colonising dark septate endophytic fungi. Stud. Mycol. 53, 173-189 (2005).

38. Jumpponen, A. \& Trappe, J. M. Dark septate endophytes: a review of facultative biotrophic root-colonizing fungi. New Phytol. 140, 195-310 (1998).

39. Liu, M. J., Zhang, X. T. \& Zhao, Z. W. Advances in the research of dark septate endophytes. Mycosystema. 028, 888-894 (2009).

40. Chen, X. M. et al. Diversity and Antimicrobial and Plant-Growth-Promoting Activities of Endophytic Fungi in Dendrobium loddigesii Rolfe. $J$ Plant Growth Regul. 29, 328-337 https://doi.org/10.1007/s00344-010-9139-y (2010).

41. Zhang, C. L. \& Guo, S. X. Study on Isolation of Endophytic fungi from Five Dendrobium Plants and Its Antimicrobial Activity. Chinese Pharmaceutical Journal. 44, 1540-1543 (2009).

42. Tan, X. M., Yu, L. Y., Zhou, Y. Q. \& Isolation Identification and Antimicrobial Activities of Endophytic Fungi of Dysosma versipellis (Hance) M. Cheng. Chinese Pharmaceutical Journal. 49, 363-366 (2014).

43. Makins, J. F., Allsop, A. \& Holt, G. Intergeneric cosynthesis of Penicillin by strains of Penicillium chrysogenum, P. chrysogenum/notatum and aspergillus nidulans. J Gen Microbiol 122, 339-343(1981). 
44. Dasu, V. \& Panda, T. Optimization of microbiological parameters for enhanced griseofulvin production using response surface methodology. Bioprocess. Eng. 22, 45-49 https://doi.org/10.1007/PL00009099 (2000).

45. Wang, Y. et al. Study on communities of endophytic fungi from Pogostemon cablin and their antimicrobial activities. Chinese Pharmaceutical Journal. 42, 657-662 (2017).

46. George, T. K., Joy, A., Divya, K. \& Jisha, M. S. In vitro and in silico docking studies of antibacterial compounds derived from endophytic penicillium setosum. Microb. Pathog. 131, 87-97 https://doi.org/10.1016/j.micpath.2019.03.033 (2019).

47. Park, Y. H. et al. Fungal endophytes inhabiting mountain-cultivated ginseng (Panax ginseng Meyer): Diversity and biocontrol activity against ginseng pathogens. Sci Rep. 7, 16221 https://doi.org/10.1038/s41598-017-16181-z (2017).

48. Chen, Y. H., Xing, X. K. \& Guo, S. X. Nutritional relationships between orchids and mycorrhizal fungi: a review. Mycosystema. 36, 807-819 (2017).

49. Batty, A. L., Brundrett, M. C., Dixon, K. W. \& Sivasithamparam, K. New methods to improve symbiotic propagation of temperate terrestrial orchid seedlings from axenic culture to soil. Australian Journal of Botany. 54, 367-374 https://doi.org/10.1071/BT04023 (2006).

50. Otero, J. T., Mosquera, A. T. \& Flanagan, N. S. Tropical orchid mycorrhizae: potential applications in orchid conservation, commercialization, and beyond. Lankesteriana. 13, 57-63 (2013).

51. Rafter, M. et al. Non-specific symbiotic germination of Cynorkis purpurea (Thouars) Kraezl., a habitat-specific terrestrial orchid from the Central Highlands of Madagascar. Mycorrhiza. 26, 541-552 https://doi.org/10.1007/s00572-016-0691-6 (2016).

52. Gao, Y., Guo, S. X. \& Xin, X. K. Fungal diversity and mechanisms of symbiotic germination of orchid seeds: a review. Mycosystema. 38, 1808-1825 (2019).

53. Yang, J. W. et al. Effects of Tulasnella sp. S7 and its extract on Dendrobium officinale seed germination. Scientia Sinica (Vitae). 50, 559-570 (2020).

54. Xu, L., Tian, J. N., Wang, T. \& Li, L. B. Symbiosis Established Between Orchid and Tulasnella spp. Fungi. Journal of Nuclear Agricultural Sciences. 31, 876883 (2017).

55. Roche, S. A. et al. A narrow group of monophyletic Tulasnella (Tulasnellaceae) symbiont lineages are associated with multiple species of Chiloglottis (Orchidaceae): Implications for orchid diversity. American Journal of Botany. 97, 1313-1327 https://doi.org/10.3732/ajb.1000049 (2010).

56. White, T. J. et al. Amplification and direct sequencing of fungal ribosomal RNA genes for phylogenetics. In: PCR protocols: A guide to methods and applications. (Innis MA, Gelfand DH, Sninsky JJ, White TJ (eds)Academic Press, New York.p 315-322, 1990).

57. Altschul, S. F. et al. Gapped BLAST and PSI-BLAST: a new generation of protein database search programs. Nucleic acids research. 25, 3389-3402 https://doi.org/10.1093/nar/25.17.3389 (1997).

58. Bosshard, P. P. et al. Ribosomal DNA sequencing for identification of aerobic Gram-positive rods in the clinical laboratory (an 18-month evaluation). Journal of Clinical Microbiology. 41, 4134-4140 (2003).

59. Cui, J. L. et al. Diversity and antioxidant activity of culturable endophytic fungi from alpine plants of Rhodiola crenulata, $R$. angusta, and $R$. sachalinensis. PLoS ONE 10(3), e0118204, https://doi.org/10.1371/journal.pone.0118204 (2015).

60. Ma, Y. M., Tian, C. L. \& Zhang, H. C. Isolation and Identification of Endophytic Fungi from Eucommia ulmoides and Screening of Their Antimicrobial Activities. Lishizhen Medicine and Materia Medica Research. 22, 552-554 (2011).

61. Tan, X. M., Wang, C. L., Chen, X. M., Zhou, Y. Q. \& Guo, S. X. In vitro seed germination and seedling growth of an endangered epiphytic orchid, dendrobium officinale, endemic to china using mycorrhizal fungi (Tulasnella sp.). Sci. Hort. 165, 62-68 https://doi.org/10.1016/j.scienta.2013.10.031 (2014).

62. Kendon, J. P. et al. Recovery of mycorrhizal fungi from wild collected protocorms of Madagascan endemic orchid Aerangis ellisii (B.S. Williams) Schltr. and their use in seed germination in vitro. Mycorrhiza 30, https://doi.org/567-576,10.1007/s00572-020-00971-x(2020).

63. Stewart, S. L., Zettler, L. W., Minso, J. \& Brown, P. M. Symbiotic Germination and Reintroduction of Spiranthes brevilabris Lindley, an Endangered Orchid Native to Florida. Selbyana. 24 (1), 64-70 https://doi.org/10.2307/41750957 (2003).

64. Maulana, A. F. et al. Nitrogen and phosphorus concentrations in growth media affect the relationship between root endophytic fungi and host plant. Arch Microbiol. 2, 1-8 https://doi.org/10.1007/s00203-021-02238-1 (2021).

65. Grafenhan, T. et al. An overview of the taxonomy, phylogeny, and typification of nectriaceous fungi in Cosmospora, Acremonium, Fusarium, Stilbella, and Volutella. Stud. Mycol. 68, 79-113 https://doi.org/10.3114/sim.2011.68.04 (2011).

66. Schmeisser, C., Steele, H. \& Streit, W. R. Metagenomics, biotechnology with non-culturable microbes. Applied Microbiology \& Biotechnology. 75, $955-962$ https://doi.org/10.1007/s00253-007-0945-5 (2007).

\section{Tables}

Table 1. Fungal endophytes from N. fordii and their isolation rate (IR\%). 


\begin{tabular}{|c|c|c|c|c|c|c|c|c|c|c|}
\hline \multirow{2}{*}{$\begin{array}{l}\text { Genus (stated in } \\
\text { GenBank) }\end{array}$} & \multirow{2}{*}{$\begin{array}{l}\text { Phylum; Class; } \\
\text { Order[Family }\end{array}$} & \multirow{2}{*}{$\begin{array}{l}\text { Fungal isolate } \\
\text { (representative } \\
\text { strains } \\
\text { number) }\end{array}$} & \multicolumn{4}{|c|}{ Isolate number } & \multicolumn{4}{|l|}{ IR (\%) } \\
\hline & & & Leaf & Rhizome & Corm & Total & Leaf & Rhizome & Corm & Tote \\
\hline Aspergillus & $\begin{array}{l}\text { Ascomycota; Eurotiomycetes; } \\
\text { Eurotiales; Aspergillaceae }\end{array}$ & $\begin{array}{l}\text { 1170, 1171, } \\
1179,1193, \\
1237,1238, \\
1252,\end{array}$ & 4 & 9 & 8 & 21 & $0.78 \%$ & $2.90 \%$ & $4.97 \%$ & 2.13 \\
\hline Unknown & $\begin{array}{l}\text { Ascomycota; Eurotiomycetes; } \\
\text { Eurotiales; Aspergillaceae }\end{array}$ & 1212 & 1 & 0 & 0 & 1 & $0.19 \%$ & 0 & 0 & $0.1 \mathrm{C}$ \\
\hline Penicillium & $\begin{array}{l}\text { Ascomycota; Eurotiomycetes; } \\
\text { Eurotiales; Aspergillaceae }\end{array}$ & 1151,1263 & 2 & 4 & 0 & 6 & $0.39 \%$ & $1.29 \%$ & 0 & 0.61 \\
\hline Talaromyces & $\begin{array}{l}\text { Ascomycota; Eurotiomycetes; } \\
\text { Eurotiales; Trichocomaceae }\end{array}$ & 1270,1283 & 1 & 0 & 1 & 2 & $0.19 \%$ & 0 & $0.62 \%$ & $0.2 \mathrm{C}$ \\
\hline Unknown & $\begin{array}{l}\text { Ascomycota; Eurotiomycetes; } \\
\text { Eurotiales; Trichocomaceae }\end{array}$ & 1295 & 0 & 0 & 1 & 1 & 0 & 0 & $0.62 \%$ & $0.1 \mathrm{C}$ \\
\hline Rhinocladiella & $\begin{array}{l}\text { Ascomycota; Eurotiomycetes; } \\
\text { Chaetothyriales; } \\
\text { Herpotrichiellaceae }\end{array}$ & 1185 & 2 & 1 & 0 & 3 & $0.39 \%$ & $0.32 \%$ & 0 & $0.3 \mathrm{C}$ \\
\hline Acrocalymma & $\begin{array}{l}\text { Ascomycota; Dothideomycetes; } \\
\text { Pleosporales; Massarineae }\end{array}$ & 1186 & 1 & 0 & 6 & 7 & $0.19 \%$ & 0 & $3.73 \%$ & 0.71 \\
\hline Letendraea & $\begin{array}{l}\text { Ascomycota; Dothideomycetes; } \\
\text { Pleosporales; Massarineae }\end{array}$ & 1239 & 1 & 0 & 0 & 1 & $0.19 \%$ & 0 & 0 & $0.1 \mathrm{C}$ \\
\hline Periconia & $\begin{array}{l}\text { Ascomycota; Dothideomycetes; } \\
\text { Pleosporales; Massarineae }\end{array}$ & 1207 & 0 & 0 & 1 & 1 & 0 & 0 & $0.62 \%$ & $0.1 \mathrm{C}$ \\
\hline Ascochyta & $\begin{array}{l}\text { Ascomycota; Dothideomycetes; } \\
\text { Pleosporales; Didymellaceae }\end{array}$ & 1213,1235 & 3 & 0 & 15 & 18 & $0.58 \%$ & 0 & $9.32 \%$ & 1.83 \\
\hline Epicoccum & $\begin{array}{l}\text { Ascomycota; Dothideomycetes; } \\
\text { Pleosporales; Didymellaceae }\end{array}$ & 1154 & 30 & 17 & 1 & 48 & $5.85 \%$ & $5.48 \%$ & $0.62 \%$ & $4.8 \varepsilon$ \\
\hline Phoma & $\begin{array}{l}\text { Ascomycota; Dothideomycetes; } \\
\text { Pleosporales; Didymellaceae }\end{array}$ & 1244,1254 & 0 & 2 & 0 & 2 & 0 & $0.65 \%$ & 0 & $0.2 \mathrm{C}$ \\
\hline Alternaria & $\begin{array}{l}\text { Ascomycota; Dothideomycetes; } \\
\text { Pleosporales; Pleosporaceae }\end{array}$ & 1211 & 0 & 2 & 0 & 2 & 0 & $0.65 \%$ & 0 & $0.2 \mathrm{C}$ \\
\hline Bipolaris & $\begin{array}{l}\text { Ascomycota; Dothideomycetes; } \\
\text { Pleosporales; Pleosporaceae }\end{array}$ & 1198 & 1 & 2 & 0 & 3 & $0.19 \%$ & $0.65 \%$ & 0 & $0.3 \mathrm{C}$ \\
\hline Exserohilum & $\begin{array}{l}\text { Ascomycota; Dothideomycetes; } \\
\text { Pleosporales; Pleosporaceae }\end{array}$ & 1205 & 1 & 1 & 0 & 2 & $0.19 \%$ & $0.32 \%$ & 0 & $0.2 \mathrm{C}$ \\
\hline Sclerostagonospora & $\begin{array}{l}\text { Ascomycota; Dothideomycetes; } \\
\text { Pleosporales; Pleosporaceae }\end{array}$ & 1303 & 0 & 1 & 0 & 1 & 0 & $0.32 \%$ & 0 & $0.1 \mathrm{C}$ \\
\hline Torula & $\begin{array}{l}\text { Ascomycota; Dothideomycetes; } \\
\text { Pleosporales; Torulaceae }\end{array}$ & 1315 & 0 & 1 & 0 & 1 & 0 & $0.32 \%$ & 0 & $0.1 \mathrm{C}$ \\
\hline Unknown & Ascomycota & $\begin{array}{l}1192,1299 \\
1310,1312\end{array}$ & 0 & 0 & 11 & 11 & 0 & 0 & $6.83 \%$ & 1.12 \\
\hline Dictyosporium & $\begin{array}{l}\text { Ascomycota; Dothideomycetes; } \\
\text { Pleosporales; Massarineae }\end{array}$ & 1180 & 0 & 0 & 3 & 3 & 0 & 0 & $1.86 \%$ & $0.3 \mathrm{C}$ \\
\hline Unknown & $\begin{array}{l}\text { Ascomycota; Dothideomycetes; } \\
\text { Pleosporales;Sporormiaceae }\end{array}$ & 1272 & 2 & 0 & 0 & 2 & $0.39 \%$ & 0 & 0 & $0.2 \mathrm{C}$ \\
\hline Unknown & $\begin{array}{l}\text { Ascomycota; Dothideomycetes; } \\
\text { Pleosporales }\end{array}$ & 1233,1236 & 0 & 0 & 8 & 8 & 0 & 0 & $4.97 \%$ & 0.81 \\
\hline Cladosporium & $\begin{array}{l}\text { Ascomycota; Dothideomycetes; } \\
\text { Cladosporiales; Cladosporiaceae }\end{array}$ & $\begin{array}{l}1135,1175 \\
1277,1280\end{array}$ & 8 & 0 & 4 & 12 & $1.56 \%$ & 0 & $2.48 \%$ & 1.22 \\
\hline Mycoleptodiscus & $\begin{array}{l}\text { Ascomycota; Dothideomycetes; } \\
\text { Muyocopronales; } \\
\text { Muyocopronaceae }\end{array}$ & 1292 & 1 & 0 & 0 & 1 & $0.19 \%$ & 0 & 0 & $0.1 \mathrm{C}$ \\
\hline Unknown & $\begin{array}{l}\text { Ascomycota; Dothideomycetes; } \\
\text { Venturiales; Venturiaceae }\end{array}$ & 1300 & 1 & 0 & 0 & 1 & $0.19 \%$ & 0 & 0 & $0.1 \mathrm{C}$ \\
\hline Unknown & $\begin{array}{l}\text { Ascomycota; Dothideomycetes; } \\
\text { Magnaporthales }\end{array}$ & 1173 & 4 & 0 & 0 & 4 & $0.78 \%$ & 0 & 0 & 0.41 \\
\hline Phyllosticta & $\begin{array}{l}\text { Ascomycota; Dothideomycetes; } \\
\text { Botryosphaeriales; } \\
\text { Phyllostictaceae }\end{array}$ & $\begin{array}{l}\text { 1108, } 1144 \\
1159,1160\end{array}$ & 52 & 1 & 0 & 53 & $10.14 \%$ & $0.32 \%$ & 0 & 5.39 \\
\hline
\end{tabular}




\begin{tabular}{|c|c|c|c|c|c|c|c|c|c|c|}
\hline Unknown & $\begin{array}{l}\text { Ascomycota; Sordariomycetes; } \\
\text { Sordariales }\end{array}$ & 1304 & 1 & 0 & 0 & 1 & $0.19 \%$ & 0 & 0 & $0.1 \mathrm{C}$ \\
\hline Amesia & $\begin{array}{l}\text { Ascomycota; Sordariomycetes; } \\
\text { Sordariales; Chaetomiaceae }\end{array}$ & 1260 & 0 & 1 & 0 & 1 & 0 & $0.32 \%$ & 0 & $0.1 \mathrm{C}$ \\
\hline Chaetomium & $\begin{array}{l}\text { Ascomycota; Sordariomycetes; } \\
\text { Sordariales; Chaetomiaceae }\end{array}$ & $\begin{array}{l}1201,1209 \\
1261\end{array}$ & 0 & 3 & 1 & 4 & 0 & $0.97 \%$ & $0.62 \%$ & 0.41 \\
\hline Colletotrichum & $\begin{array}{l}\text { Ascomycota; Sordariomycetes; } \\
\text { Glomerellales; Glomerellaceae }\end{array}$ & $\begin{array}{l}1101,1107, \\
1136, \\
1139,1147, \\
1153,1188, \\
1203,1206, \\
1215,1242, \\
1257,1284\end{array}$ & 93 & 4 & 4 & 101 & $18.13 \%$ & $1.29 \%$ & $2.48 \%$ & 10.2 \\
\hline Cylindrocarpon & $\begin{array}{l}\text { Ascomycota; Sordariomycetes; } \\
\text { Hypocreales; Nectriaceae }\end{array}$ & 1230 & 0 & 9 & 11 & 20 & 0 & $2.90 \%$ & $6.83 \%$ & 2.03 \\
\hline Fusarium & $\begin{array}{l}\text { Ascomycota; Sordariomycetes; } \\
\text { Hypocreales; Nectriaceae }\end{array}$ & $\begin{array}{l}1119,1133 \\
1222, \\
1225,1286\end{array}$ & 17 & 20 & 21 & 58 & $3.31 \%$ & $6.45 \%$ & $13.04 \%$ & $5.8 \mathrm{C}$ \\
\hline Ilyonectria & $\begin{array}{l}\text { Ascomycota; Sordariomycetes; } \\
\text { Hypocreales; Nectriaceae }\end{array}$ & 1265 & 0 & 1 & 0 & 1 & 0 & $0.32 \%$ & 0 & $0.1 \mathrm{C}$ \\
\hline Purpureocillium & $\begin{array}{l}\text { Ascomycota; Sordariomycetes; } \\
\text { Hypocreales;Ophiocordycipitaceae }\end{array}$ & 1314 & 0 & 1 & 0 & 1 & 0 & $0.32 \%$ & 0 & $0.1 \mathrm{C}$ \\
\hline Nectria & $\begin{array}{l}\text { Ascomycota; Sordariomycetes; } \\
\text { Hypocreales; Nectriaceae }\end{array}$ & 1288 & 1 & 2 & 1 & 4 & $0.19 \%$ & $0.65 \%$ & $0.62 \%$ & 0.41 \\
\hline Volutella & $\begin{array}{l}\text { Ascomycota; Sordariomycetes; } \\
\text { Hypocreales; Nectriaceae }\end{array}$ & 1251 & 0 & 0 & 2 & 2 & 0 & 0 & $1.24 \%$ & $0.2 \mathrm{C}$ \\
\hline Corallomycetella & $\begin{array}{l}\text { Ascomycota; Sordariomycetes; } \\
\text { Hypocreales; Nectriaceae }\end{array}$ & 1307 & 0 & 1 & 0 & 1 & 0 & $0.32 \%$ & 0 & $0.1 \mathrm{C}$ \\
\hline Lecanicillium & $\begin{array}{l}\text { Ascomycota; Sordariomycetes; } \\
\text { Hypocreales; Cordycipitaceae }\end{array}$ & 1262 & 0 & 0 & 1 & 1 & 0 & 0 & $0.62 \%$ & $0.1 \mathrm{C}$ \\
\hline Arthrinium & $\begin{array}{l}\text { Ascomycota; Sordariomycetes; } \\
\text { Xylariales; Apiosporaceae }\end{array}$ & $\begin{array}{l}1103,1105 \\
1124,1130 \\
1163,1232\end{array}$ & 202 & 40 & 22 & 264 & $39.38 \%$ & $12.90 \%$ & $13.66 \%$ & $26 . \varepsilon$ \\
\hline Obolarina & $\begin{array}{l}\text { Ascomycota; Sordariomycetes; } \\
\text { Xylariales; Xylariaceae }\end{array}$ & 1148 & 11 & 0 & 0 & 11 & $2.14 \%$ & 0 & 0 & 1.12 \\
\hline Xylaria & $\begin{array}{l}\text { Ascomycota; Sordariomycetes; } \\
\text { Xylariales; Xylariaceae }\end{array}$ & 1184 & 1 & 0 & 0 & 1 & $0.19 \%$ & 0 & 0 & $0.1 \mathrm{C}$ \\
\hline Daldinia & $\begin{array}{l}\text { Ascomycota; Sordariomycetes; } \\
\text { Xylariales; Hypoxylaceae }\end{array}$ & 1200 & 0 & 1 & 0 & 1 & 0 & $0.32 \%$ & $0.00 \%$ & $0.1 \mathrm{C}$ \\
\hline Diaporthe & $\begin{array}{l}\text { Ascomycota; Sordariomycetes; } \\
\text { Diaporthales; Diaporthae }\end{array}$ & 1204,1220 & 0 & 3 & 5 & 8 & 0 & $0.97 \%$ & $3.11 \%$ & 0.81 \\
\hline Phomopsis & $\begin{array}{l}\text { Ascomycota; Sordariomycetes; } \\
\text { Diaporthales; Valsaceae }\end{array}$ & 1202 & 0 & 3 & 3 & 6 & 0 & $0.97 \%$ & $1.86 \%$ & 0.61 \\
\hline Unknown & $\begin{array}{l}\text { Ascomycota; Sordariomycetes; } \\
\text { Magnaporthales; } \\
\text { Magnaporthaceae }\end{array}$ & 1104 & 8 & 1 & 0 & 9 & $1.56 \%$ & $0.32 \%$ & 0 & 0.91 \\
\hline Leptostroma & $\begin{array}{l}\text { Ascomycota; Leotiomycetes; } \\
\text { Rhytismatales; Rhytismataceae }\end{array}$ & 1167,1176 & 5 & 0 & 0 & 5 & $0.97 \%$ & 0 & 0 & 0.51 \\
\hline Unknown & Basidiomycota; Agaricomycetes; & 1129 & 0 & 3 & 15 & 18 & 0 & $0.97 \%$ & $9.32 \%$ & 1.83 \\
\hline Epulorhiza & $\begin{array}{l}\text { Basidiomycota; Agaricomycetes; } \\
\text { Cantharellales; Tulasnellaceae }\end{array}$ & 1158 & 0 & 4 & 0 & 4 & 0 & $1.29 \%$ & 0 & 0.41 \\
\hline Unknown & $\begin{array}{l}\text { Basidiomycota; Agaricomycetes; } \\
\text { Cantharellales; Tulasnellaceae }\end{array}$ & 1217 & 1 & 160 & 2 & 163 & $0.19 \%$ & $51.61 \%$ & $1.24 \%$ & 16.5 \\
\hline Phanerochaete cf. & $\begin{array}{l}\text { Basidiomycota; Agaricomycetes; } \\
\text { Polyporales; Phanerochaetaceae }\end{array}$ & 1141 & 2 & 0 & 0 & 2 & $0.39 \%$ & 0 & 0 & $0.2 \mathrm{C}$ \\
\hline $\begin{array}{l}\text { Fungal endophyte } \\
\text { sp. and fungal sp. }\end{array}$ & & $\begin{array}{l}1109,1120, \\
1149, \\
1168,1172, \\
1187,1191, \\
1228,1240, \\
1253,1255, \\
1264,1266, \\
1278,1290, \\
1308,1305\end{array}$ & 38 & 8 & 8 & 54 & $7.41 \%$ & $2.58 \%$ & $4.97 \%$ & $5.4 \mathrm{C}$ \\
\hline
\end{tabular}




\begin{tabular}{|c|c|c|c|c|c|c|c|c|}
\hline Unidentified fungi & $\begin{array}{l}\text { 1106, 1169, } \\
\text { 1174, 1183, } \\
\text { 1189, 1190, } \\
\text { 1195, 1197, } \\
1216,1229 \\
1247,1309\end{array}$ & 18 & 4 & 6 & 28 & $3.51 \%$ & $1.29 \%$ & $3.73 \%$ \\
\hline Individual number & & 513 & 310 & 161 & 984 & $52.13 \%$ & $31.50 \%$ & $16.36 \%$ \\
\hline Shannon index $(H)$ & & 1.976 & 1.923 & 2.686 & & & & \\
\hline $\begin{array}{l}\text { Pielou Evenness } \\
\text { index }(\mathcal{J})\end{array}$ & & 0.600 & 0.565 & 0.835 & & & & \\
\hline
\end{tabular}

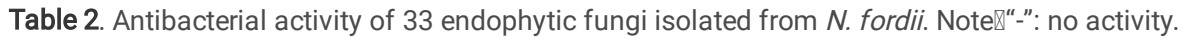

\begin{tabular}{|c|c|c|c|c|}
\hline No. & Plant part & $\begin{array}{l}\text { Escherichia coli } \\
\text { (inhibitory zone [mm]) }\end{array}$ & $\begin{array}{l}\text { Staphylococcus aureus } \\
\text { (inhibitory zone [mm]) }\end{array}$ & $\begin{array}{l}\text { Candida tropicalis } \\
\text { (inhibitory zone [mm]) }\end{array}$ \\
\hline 1151 & Leaf, rhizome & 34.698 & 28.478 & - \\
\hline 1154 & Leaf, rhizome, corm & 22.115 & 15.702 & - \\
\hline 1174 & leaf & - & 9.657 & - \\
\hline 1211 & rhizome & - & 8.673 & - \\
\hline 1221 & rhizome & - & 9.952 & 12.107 \\
\hline 1224 & rhizome & 15.675 & - & - \\
\hline 1230 & rhizome & 9.958 & - & - \\
\hline 1231 & rhizome & 12.060 & 12.520 & - \\
\hline 1232 & leaf & - & 8.740 & - \\
\hline 1238 & leaf & 11.592 & - & - \\
\hline 1243 & rhizome & 18.515 & 19.540 & - \\
\hline 1244 & rhizome & 20.690 & 21.298 & - \\
\hline 1250 & rhizome & 9.955 & - & - \\
\hline 1252 & corm & 8.515 & - & - \\
\hline 1260 & rhizome & - & 8.730 & - \\
\hline 1262 & corm & 9.142 & 9.042 & - \\
\hline 1266 & leaf, rhizome & - & 10.580 & - \\
\hline 1273 & rhizome, corm & 11.075 & 10.270 & - \\
\hline 1303 & rhizome & 11.078 & - & 9.838 \\
\hline 1306 & rhizome, corm & - & 9.445 & - \\
\hline $5 \mathrm{mg} \cdot \mathrm{mL}^{-1} 20 \mu \mathrm{L}$ streptomycin & & 24.477 & 23.336 & - \\
\hline $5 \mathrm{mg} \cdot \mathrm{mL}^{-1} 20 \mu \mathrm{L}$ tetracycline & & 26.439 & 24.850 & - \\
\hline
\end{tabular}

Table 3. Seed germination and protocorm development in $N$. fordi $i^{63}$.

\begin{tabular}{|ll|}
\hline Stage & Description \\
\hline 0 & No germination, viable embryo \\
\hline 1 & Enlarged embryo, production of rhizoid(s) (=germination) \\
\hline 2 & Continued embryo enlargement, testa rupture, further rhizoid production \\
\hline 3 & Appearance of the protomeristem \\
\hline 4 & Emergence of first leaf \\
\hline 6 & Elongation of first leaf \\
\hline 7 & Emergence of second leaf \\
\hline 8 & Appearance of root \\
\hline
\end{tabular}

Page 10/12 
Figures
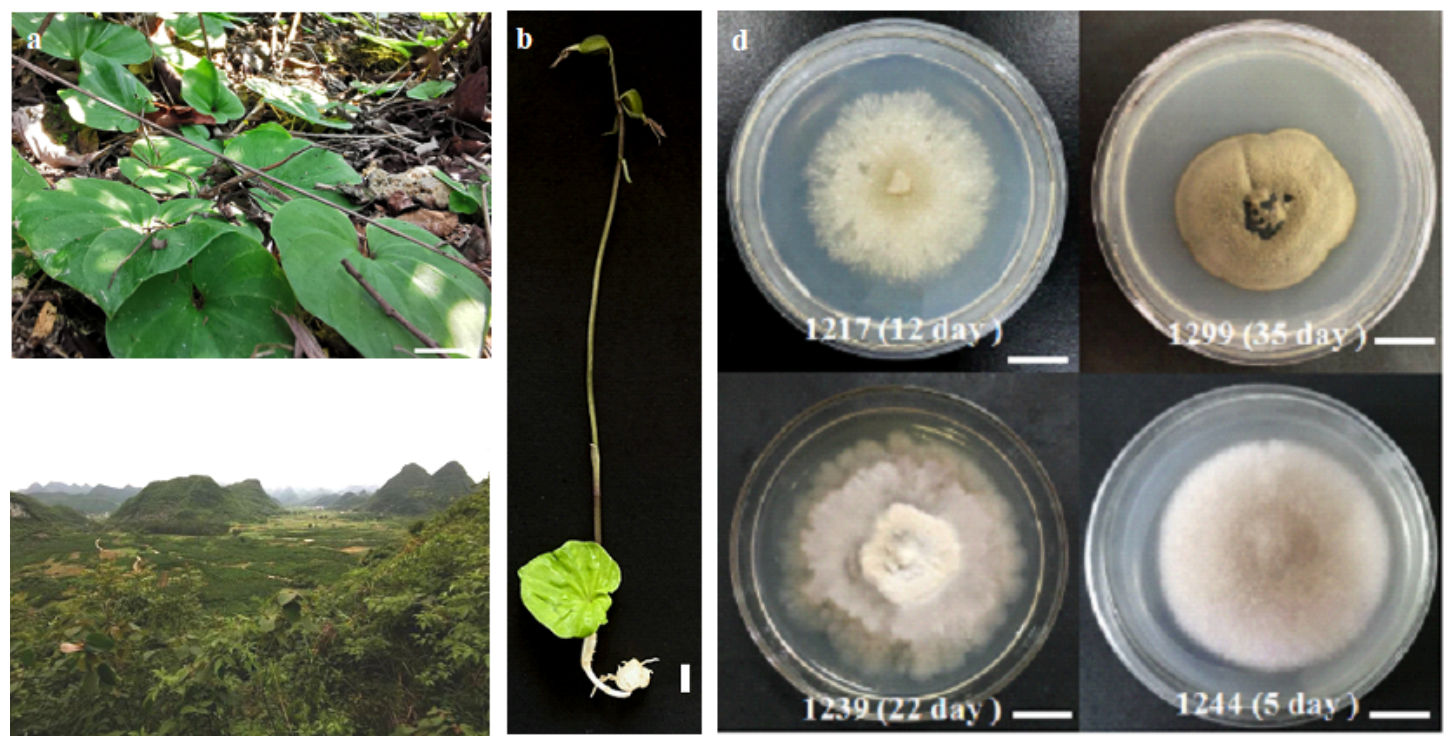

Figure 1

Wild N. fordii plant samples and their endophytic fungi. (a) Plants of N. fordii growing among on a hillside, bar =1cm; (b) the whole plant (including rhizome), bar =1cm; (c) habitat; (d) representative fungal morphotypes isolated from N. fordii grown on potato dextrose agar at $26^{\circ} \mathrm{C}, \mathrm{bar}=0.5 \mathrm{~cm}$.
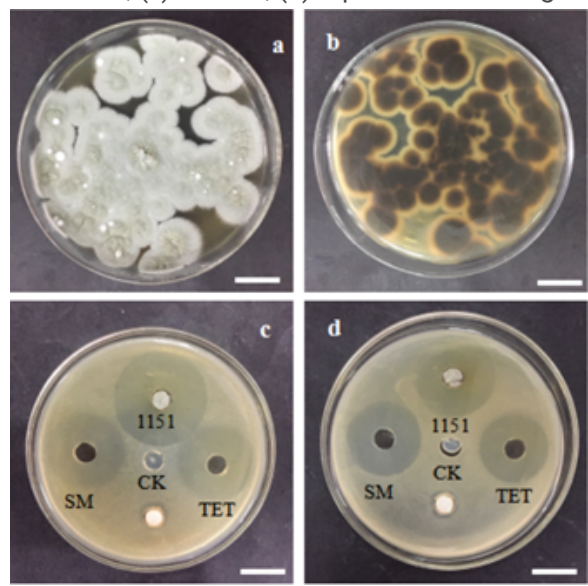

\section{Figure 2}

Antimicrobial activity of some strains. (a-b) morphological characteristics of strain 1151; (c) Antibacterial activity of 1151 against E. coli; (d) antibacterial activity of 1151 against $\mathrm{S}$. aureus. Bar: $\mathrm{a}-\mathrm{d}=1 \mathrm{~cm}$.

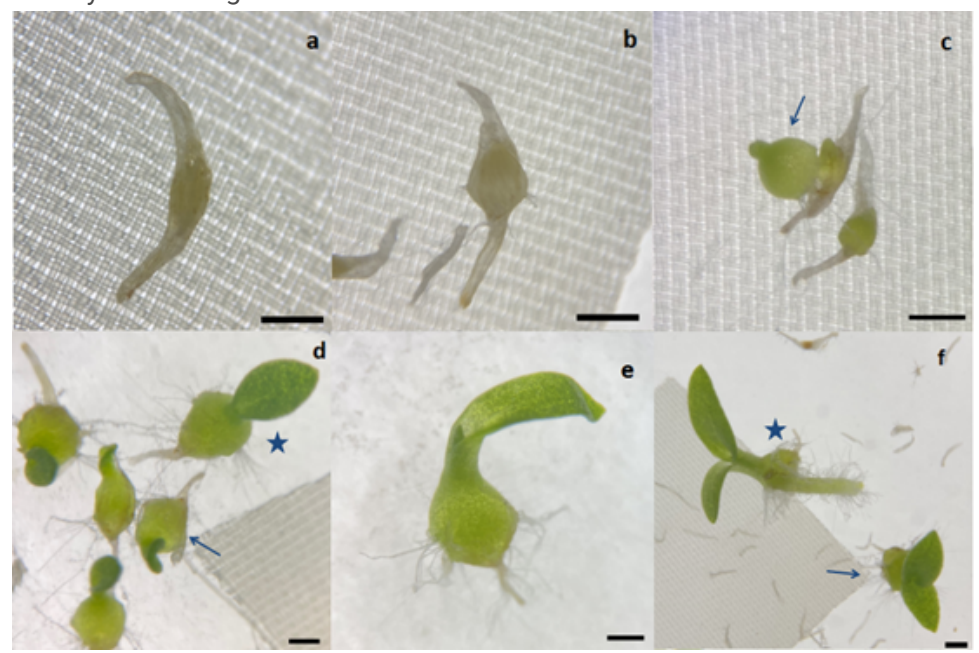

Figure 3 
Symbiotic seed germination and protocorm developmental stages of B.striata cultured with the mycorrhizal fungal strain 1217 (Tulasnellaceae sp.) cultured on oatmeal agar at 10 weeks after sowing; (a) stage 0; (b) stage 1 (shown by arrow); stage 2 (shown by star); (c) stage 3 (shown by arrow); (d) stage 4 (shown by arrow); stage 5 (shown by star) of protocorm development (note the elongation of the first leaf); (e) stage 6; (f) tage 7 (shown by arrow); and stage 8 (shown by star). Bar: $a-f=500 \mu \mathrm{m}$.

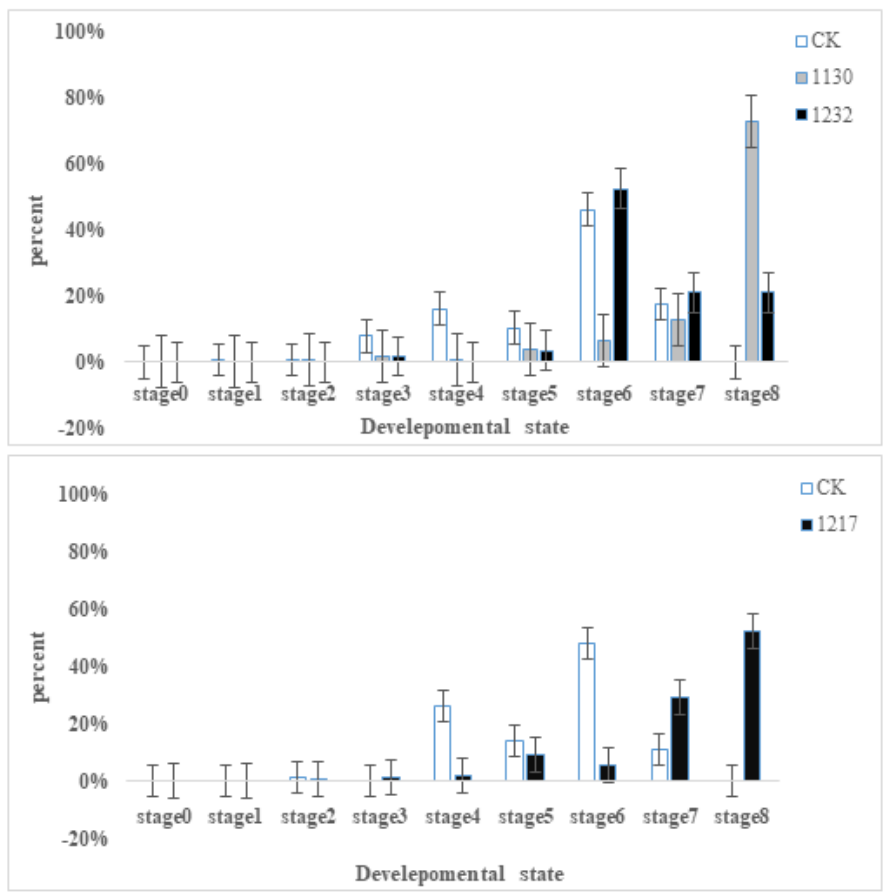

\section{Figure 4}

Effects of mycorrhizal fungi on the seed germination of B.striata 7 weeks after sowing. (a) Arthrinium sp. (1130 and 1232); (b) Tulasnellaceae sp. (1217). Note: the results show the mean of three replicates with bars indicating the standard error. 